\title{
Flora do Parque Nacional do Catimbau, Pernambuco, Brasil: Boraginaceae sensu lato
}

\author{
José Iranildo Miranda de Melo \\ Universidade Estadual da Paraíba, Centro de Ciências Biológicas e da Saúde \\ Departamento de Biologia, PPG em Ecologia \& Conservação \\ CEP 58429-500, Campina Grande - PB, Brasil \\ tournefort@gmail.com
}

Submetido em 08/05/2012

Aceito para publicação em 14/08/2012

\section{Resumo}

A família Boraginaceae Juss. engloba plantas herbáceas a arbóreas, ramos portando folhas alternas a subopostas, flores bissexuadas, actinomorfas, com ou sem brácteas, e frutos drupáceos ou esquizocárpicos. Este trabalho consiste no estudo taxonômico de Boraginaceae sensu lato no Parque Nacional do Catimbau, no semiárido do estado de Pernambuco, Nordeste do Brasil. Foram registrados cinco gêneros e 12 espécies: Cordia L., Euploca Nutt., Heliotropium L. e Tournefortia L., com duas espécies cada, e Varronia P.Br., com quatro espécies. Foram elaboradas descrições, ilustrações e chaves para separação das espécies, e foram apresentados dados da distribuição geográfica e dos habitats das espécies encontradas na área de estudo.

Palavras-chave: Brasil; Semiárido; Taxonomia

\section{Abstract}

Flora of the Catimbau National Park, Pernambuco, Brazil: Boraginaceae sensu lato. The Boraginaceae Juss. family comprises from woody to herbaceous plants, branches with alternate to subopposite leaves, bisexual, actinomorphic flowers, with or without bracts, and drupaceous or schizocarp fruits. This paper consists in a taxonomic study of Boraginaceae sensu lato in the Catimbau National Park, at the semiarid region of the state of Pernambuco, Northeastern Brazil. Five genera and twelve species were registered: Cordia L., Euploca Nutt., Heliotropium L., and Tournefortia L., with two species each, and Varronia P.Br., with four species. Descriptions, illustrations, and keys were prepared for the separation of species, and data on the geographic distribution and habitats of the species found in the study area were presented.

Key words: Brazil; Semi-arid; Taxonomy 


\section{Introdução}

A família Boraginaceae sensu Cronquist (1981) está subordinada à Ordem Lamiales juntamente com Lamiaceae, Lennoaceae e Verbenaceae. Agrega cerca de 130 gêneros e 2.500 espécies e está distribuída por todo o mundo, principalmente na região mediterrânea, Américas do Norte (México), Central e do Sul.

Caracteriza-se, morfologicamente, por reunir ervas, subarbustos, árvores ou, menos frequentemente, lianas. As folhas são simples, alternas dísticas ou verticiladas e, mais raramente, subopostas a opostas. As inflorescências são folhosas ou não, com ou sem brácteas, terminais, axilares ou internodais, variando de paniculiformes, espiciformes, escorpióides, gloméruloglobosas ou, mais raramente, apresentam flores isoladas na região axilar ou supra-axilar (Euploca). As flores são pentâmeras, regulares, o cálice é gamossépalo e a corola é gamopétala. Os frutos são carnosos (drupáceos) ou secos (esquizocárpicos) estes com mericarpos denominados núculas.

De acordo com Judd et al. (1999), Boraginaceae configura na Ordem Solanales. No entanto, de acordo com o ANGIOSPERM PHYLOGENY GROUP I e II (1998; 2003), Albach et al. (2001), Bremer et al. (2002) e Soltis et al. (2002), esta família apresenta posicionamento incerto e, por esta razão não havia, até o momento, sido incluída ao nível de Ordem, provavelmente constituindo a Ordem Boraginales, conforme sugerido por Böhle e Hilger (1997) e Gottschling et al. (2001). Segundo o ANGIOSPERM PHYLOGENY GROUP III (2009), Boraginales pertence ao core das Eudicotiledôneas, Euasterídeas I, Lamiídeas, e inclui as famílias Boraginaceae, Codonaceae, Cordiaceae, Ehretiaceae, Heliotropiaceae e Hydrophyllaceae.

Para o Brasil, estudos revisionais enfocando os gêneros de Boraginaceae $s$.l. foram realizados por Taroda (1984), Melo e Semir (2008; 2010) e Cavalheiro et al. (2011).

O presente trabalho consiste no tratamento taxonômico de Boraginaceae sensu lato para o Parque Nacional do Catimbau (PNC), na região semiárida do estado de Pernambuco, de modo a apresentar informações taxonômicas e da representatividade da família para a flora de Pernambuco e, especialmente, para o semiárido do Nordeste brasileiro.

\section{Material e Métodos}

\section{Área de estudo}

O Parque Nacional do Catimbau (PNC), com $62.300 \mathrm{~km}^{2}$, abrange parte dos municípios de Buíque, Ibimirim e Tupanatinga, no estado de Pernambuco, nordeste do Brasil (Figura 1). Está posicionado a

FIGURA 1: Localização da área de estudo, Parque Nacional do Catimbau (PNC), Pernambuco, Brasil.

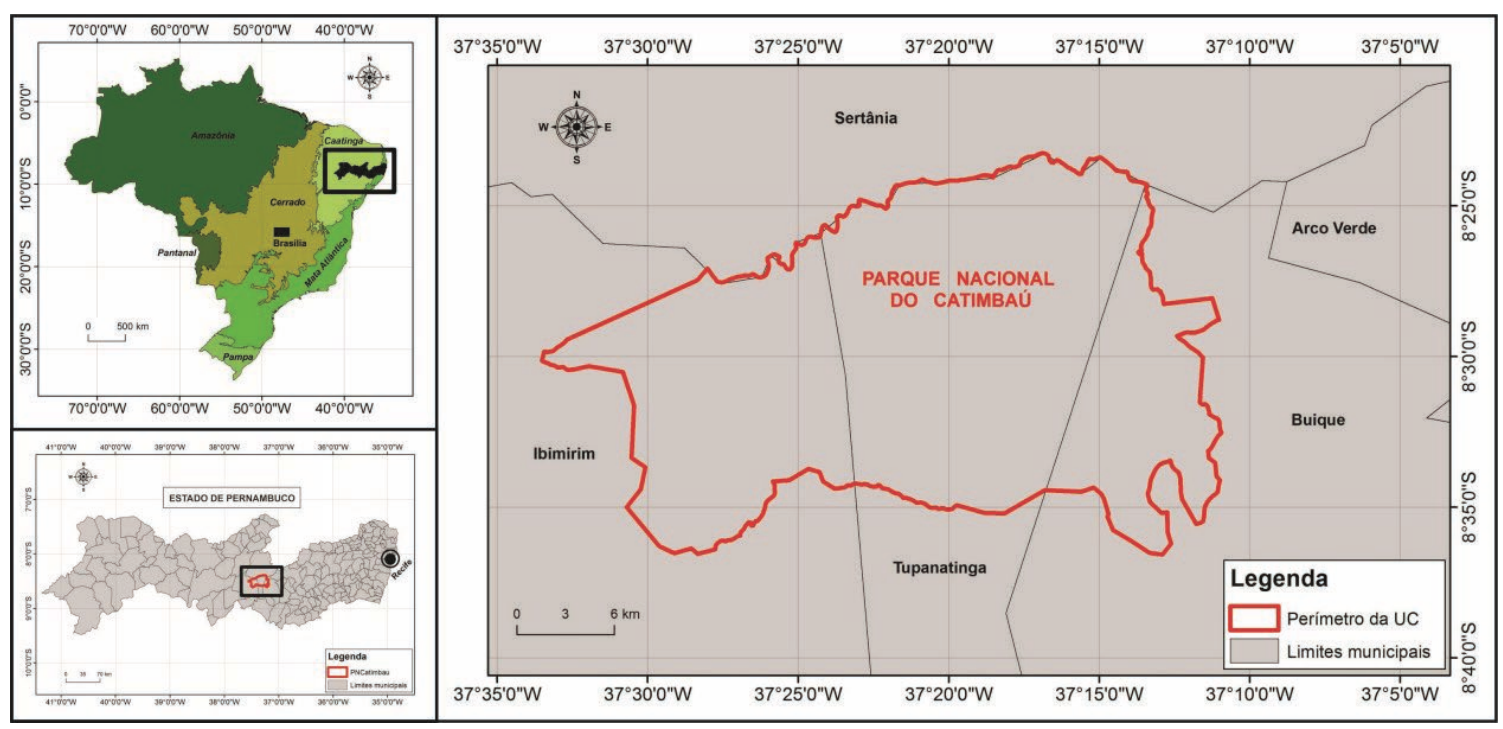


aproximadamente $300 \mathrm{~km}$ de Recife, na região chamada Sertão do Moxotó (zona de transição entre a Caatinga e o Agreste de Pernambuco). O nome Catimbau advém da serra de Catimbau, pertencente à Chapada de São José, localizada no distrito de Catimbau, em Buíque. Grande parte da área física do Parque compreende as movimentações do acidente orográfico conhecido como chapada de São José, em Buíque. Esta chapada foi formada pelo soerguido de sedimentos cretáceos, depositados sobre depressões tectônicas do escudo cristalino, do Pré-Cambriano, dentro da bacia sedimentar cretácea da série Tucano-Jatobá, na área de drenagem do rio Moxotó (JACOMINE et al., 1973). É formada por serras e morros que constituem relevos testemunhos de uma área contínua de arenitos que ligavam a chapada de São José e as serras do Quiridalho e do Parafuso, em Buíque, mais para oeste a Serra Negra e do Piriquito, no município de Inajá, e em direção do sudoeste, a Serra de Tacaratu (MOREIRA, 1977). Estas áreas de arenitos cretáceos e pós-cretáceos medem aproximadamente $160 \mathrm{~km}$ de extensão na direção sudoeste e cerca de $60 \mathrm{~km}$ de largura, além de uma área isolada nas margens do rio Pajeú (ANDRADE, 1954).

\section{Tratamento taxonômico}

As análises morfológicas comparativas foram realizadas nas dependências da Área de Botânica da Universidade Estadual da Paraíba (UEPB), Campus I, em Campina Grande, PB, com base em espécimes obtidos no PNC depositados no Herbário PEUFR (João Vasconcelos-Sobrinho) da Universidade Federal Rural de Pernambuco (UFRPE). As identificações taxonômicas fundamentaram-se na literatura especializada e em seguida, foram elaboradas descrições e chaves de identificação para as espécies deste estudo.

As descrições taxonômicas foram baseadas nas terminologias de Radford et al. (1974) e Harris e Harris (1997). Os tipos de indumento foram fundamentados em Payne (1978) e Hewson (1988), e para os tipos de venação adotou-se o trabalho de Hickey (1973).

Os tipos de inflorescências foram verificados em Strasburger et al. (1974) e Weberling (1995). A grafia dos nomes dos autores das espécies foi confirmada na lista de espécies da flora do Brasil (MELO et al., 2010; 2012). Também foram incluídos dados sobre distribuição geográfica, habitats, floração e frutificação para as espécies com base nas informações contidas nos rótulos das exsicatas analisadas.

\section{Resultados e Discussão}

No Parque Nacional do Catimbau foram encontradas 12 espécies em cinco gêneros associadas principalmente à ambientes abertos.

Boraginaceae Juss., Gen. Pl.: 128. 1789.

Árvores, arbustos, subarbustos, lianas ou ervas. Folhas alternas, subopostas, raramente verticiladas, simples, desprovidas de estípulas; pecioladas ou sésseis; lâmina com distintos formatos. Inflorescências terminais, falsamente terminais, laterais, axilares ou internodais, escorpióides, espiciformes, gloméruloglobosas ou paniculiformes, laxas ou congestas. Flores bracteadas ou desprovidas de brácteas; corola salverforme, tubular, tubular-salverforme, tubularcampanulada ou obcampanulada, creme, lilás ou alva, fauce geralmente amarela; estames 5, epipétalos, opostos aos lobos da corola, inclusos ou exsertos, anteras livres ou conatas, com ou sem apêndices, deiscência longitudinal; ovário 2-locular ou 4-locular pela intrusão de um falso septo, súpero, óvulos 1-2 por lóculo, anátropos ou hemi-anátropos, placentação axial ou basal; estilete inteiro, raro levemente bífido no ápice, ou 2-bifurcado, terminal, cilíndrico ou subcilíndrico; estigma séssil, subséssil ou com estilete evidente, com distintos formatos. Frutos secos ou carnosos, deiscentes ou indeiscentes, drupáceos ou esquizocárpicos com 2 ou 4 núculas. Sementes 1-2 por lóculo; embrião plano ou curvo. 


\section{Chave para as espécies de Boraginaceae do Parque Nacional do Catimbau}

1. Arbustos ou arvoretas a árvores; estigmas-4, oriundos de dois ramos estigmáticos bifurcados

2. Inflorescências paniculiformes

3. Ramos subtetrangulares; cálice nunca costado, rufo

1. Cordia rufescens

3. Ramos subcilíndricos; cálice costado.

2. Cordia trichotoma

2. Inflorescências espiciformes ou glomérulo-globosas

4. Inflorescências espiciformes

5. Lâmina foliar lanceolada, concolor, base atenuada

..9. Varronia curassavica

5. Lâmina foliar ovada, discolor, base levemente cordada.

10. Varronia dardani

4. Inflorescências glomérulo-globosas

6. Lacínios do cálice com ápice cirroso; corola ca. 4,5mm compr.

11. Varronia globosa

6. Lacínios do cálice com ápice agudo; corola 2,2-3,3cm compr 12. Varronia leucocephala

1. Ervas, subarbustos ou raramente arbustos; estigma-1, inteiro ou raro levemente bífido no ápice

7. Arbustos; lobos da corola involutos

8. Folhas concolores; ovário obclavado; estigma sub-peltado.

7. Tournefortia rubicunda

8. Folhas discolores; ovário cônico-piramidal; estigma estreitamente-cônico

8. Tournefortia salzmannii

7. Ervas ou subarbustos; lobos da corola patentes ou reflexos

9. Fruto com quatro núculas

10. Anteras livres entre si

3. Euploca procumbens

10. Anteras coerentes entre si

4. Euploca ternata

9. Fruto com duas núculas

11.Pecíolo parcialmente alado; fruto mitriforme, costado.

6. Heliotropium elongatum

11.Pecíolo não alado; fruto subgloboso, vesiculoso.

5. Heliotropium angiospermum

1. Cordia rufescens A.DC., Prodr. 9: 476. 1845.

Arbusto, ca. $3 \mathrm{~m}$ alt.; ramos subtetrangulares, sulcados, rufos ou não, vilosos. Folhas alternas espiraladas; lâmina 4,4-15x2,3-7,5cm, cartácea, discolor, elíptica a obovada, ápice agudo ou arredondado, margem inteira, crenada até denteada apenas na região superior, vilosa, base cuneada, face adaxial estrigilosa, face abaxial tomentosa, rufa; pecíolo 0,3-1,2cm compr.; venação broquidódroma. Inflorescência $1,5-12,5 \mathrm{~cm}$ compr., panícula terminal, raque híspida, rufa; pedúnculo 1,7-4,8cm compr. Flores ca. 4cm compr., sésseis; cálice 1-1,2cm compr., tomentoso, lacínios 2-2,5x2-3,5mm, levemente desiguais entre si, largamente ovados a depresso-ovados; corola ca. $3,6 \mathrm{~cm}$ compr., tubularsalverforme, constrição ca. $0,8 \mathrm{~cm}$ compr. da base do tubo, alva, com máculas acastanhadas, externamente estrigilosa, internamente glabrescente, lobos orbiculares; estames inseridos a ca. $0,5 \mathrm{~cm}$ da base do tubo, vilosos até a metade do seu comprimento, anteras ca. $3,5 \mathrm{~mm}$ compr., divaricatas, oblongas, filetes 1,3-1,7cm compr.; ovário ca. $2 \mathrm{~mm}$ compr., subgloboso, óvulo-1; estilete ca. $1,5 \mathrm{~cm}$ compr., cilíndrico; ramos estigmáticos subcilíndricos, bifurcando-se a ca. $3,7 \mathrm{~mm}$ do seu comprimento, estigmas ca. $0,2 \mathrm{~mm}$ compr., capitados. 
Drupa não observada.

Material examinado: BRASIL, Pernambuco: Buíque, Reserva Indígena Kapina-Wá, 0491'42”S 3762'22'”, R.S. Pinho 20, 29.Ago.2004, fl. (PEUFR). Ibidem, Serra do Catimbau, $08^{\circ} 37^{\prime}$ 'S $-37^{\circ} 10^{\prime} \mathrm{W}$, M.J.N. Rodal 388, 17.Set.1994, fl., fr. (PEUFR). Ibidem, Estrada Buíque-Catimbau, $08^{\circ} 37^{\prime}$ S $-37^{\circ} 10^{\prime}$ W, S.I. Silva et al. 770, 11.Fev.1995, fl. (PEUFR). Ibidem, Catimbau, Trilha das Torres, $08^{\circ} 37^{\prime} \mathrm{S}-37^{\circ} 10^{\prime} \mathrm{W}$, A. Laurênio \& L. Figueiredo 26, 17.Mar.1995, fl. (PEUFR). Ibimirim, Estrada Ibimirim-Petrolândia, M.J.N. Rodal et al. 494, 10.Mar.1995, fl. (PEUFR). Ibidem, Estrada IbimirimPetrolândia, 08³6'S - 38³4'W, M. Oliveira \& M. Tschá 142, 11.Dez.1995, fl. (PEUFR).

Cordia rufescens ocorre apenas no Brasil, nas regiões Nordeste (MA, PI, CE, PB, PE, BA, AL), Centro-
Oeste (GO) e Sudeste (MG) (MELO et al., 2010). No trecho estudado, encontra-se em solos arenosos e arenoargilosos associada à vegetação perenifólia arbustivoarbórea no complexo caatinga-campo, alcançando 790m de altitude. Encontrada florida em fevereiro, março, agosto, setembro e dezembro e frutificada em setembro.

Esta espécie distinguiu-se das espécies de Cordia registradas no PNC pelos ramos subtetrangulares, geralmente rufos com folhas alternas, espiraladas, bem como pela inflorescência paniculada portando flores com cálice tomentoso, rufo.

Ilustrações desta espécie podem ser encontradas em Melo e Andrade (2007).

2. Cordia trichotoma (Vell.) Arráb. ex Steud., Nomencl. Bot. 419: 1840. Figura 2: A

FIGURA 2: Espécies de Boraginaceae da área de estudo, Parque Nacional do Catimbau, Pernambuco, Brasil. A. Cordia trichotoma - inflorescências. B. Euploca ternata: B. Hábito; B1. Detalhe da inflorescência. C. Heliotropium elongatum - detalhe da inflorescência. D. Tournefortia salzmannii - ramo reprodutivo, evidenciando botões e frutos. E. Varronia globosa inflorescência. F. Varronia leucocephala - inflorescência.

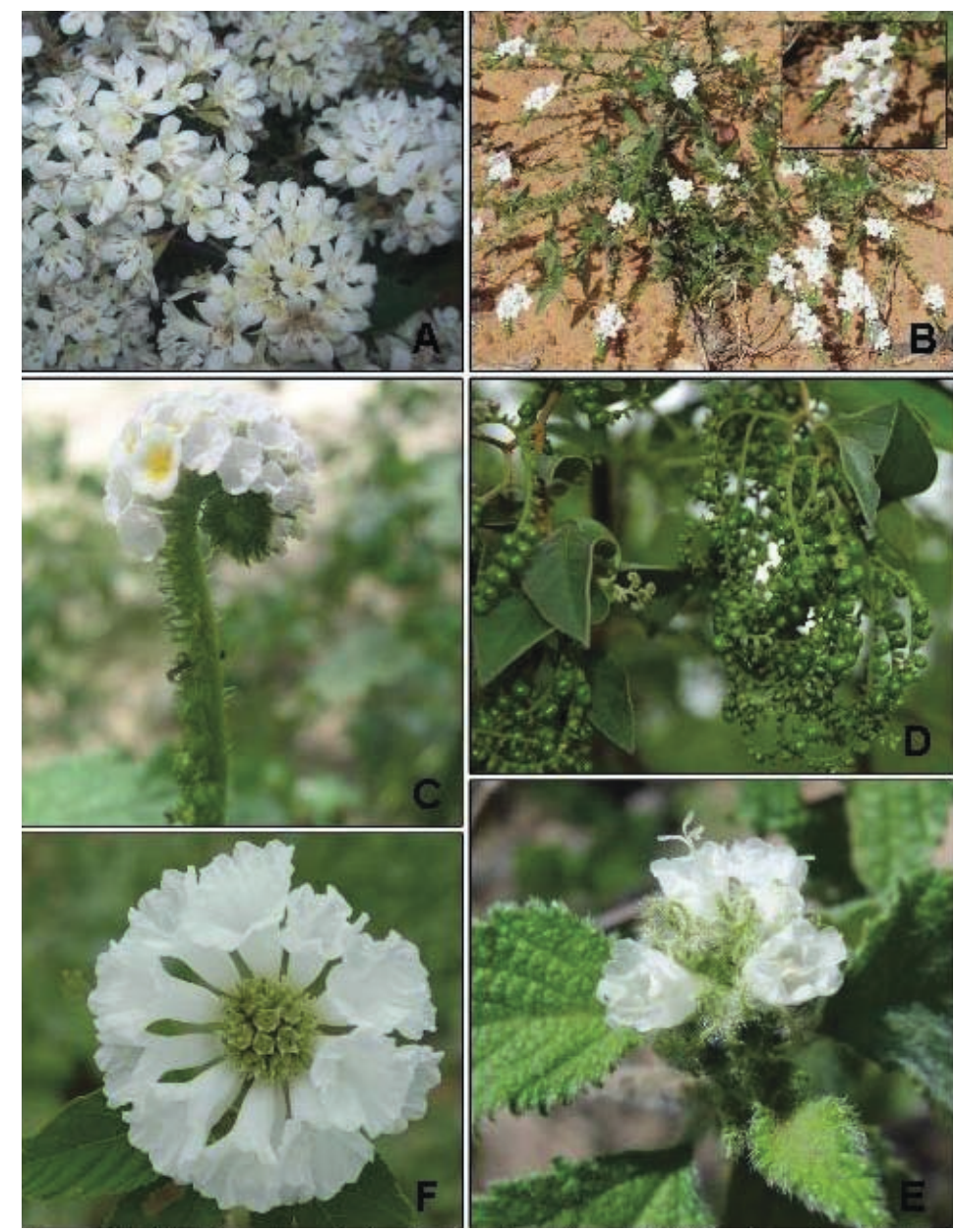


Árvore ca. 4-10m alt.; ramos subcilíndricos, recobertos de tricomas estrelados. Folhas alternas; lâmina 9-12x4-6cm, elíptica, oval lanceolada, raro arredondada, ápice agudo, margem plana ou levemente revoluta, base aguda, obliqua ou arredondada; face adaxial com tricomas estrelados em densidade variada; face abaxial densamente recoberta de tricomas estrelados; pecíolo 1,5-3cm compr. Inflorescência 10$15 \mathrm{~cm}$ compr., paniculada; pedúnculo $2-10 \mathrm{~cm}$ compr. Flores heterostílicas e homostílicas; cálice $6-7 \mathrm{~cm}$ compr., evidentemente costado, tubular cilíndrico, 5-denteados, densamente piloso apresentando tricomas estrelados; corola hipocrateriforme, tubo ca $0,8 \mathrm{~cm}$ compr., creme, lobos ca. $0,7 \mathrm{~cm}$ compr., oblongos; estame ca. $0,7 \mathrm{~cm}$ compr. com a base do filete provido de tricomas longos; ovário 2,5mm compr., subpiriforme; estilete ca. $0,7 \mathrm{~cm}$ compr. nas brevistilas, $1,0 \mathrm{~cm}$ compr. nas homostilas e 1,3cm compr. nas longistilas; estigmas foliáceos. Drupa não observada.

Material examinado: BRASIL, Pernambuco: Buíque, Estrada Buíque-Catimbau, 08³7'30"S 3709'15"W, L. Figueiredo et al. 148, 17.VIII.1995, fl. (PEUFR). Ibimirim, Baixa da Faveleira, 08³7'30"S -37099'15”'W, L.M. Nascimento et al. 11, 01.Set.1996, bot. fl. (PEUFR).

Esta espécie encontra-se amplamente distribuída no Brasil, associada a ambientes de cerrado, florestas e em caatingas (RANGA et al., 2011). No PNC foi registrada em solo arenoso em altitudes que variaram de 799-1100m. Encontrada com botões florais em setembro e com flores em agosto e setembro.

Assemelha-se morfologicamente à Cordia rufescens, no entanto, distingui-se desta especialmente pelos ramos subcilíndricos, nunca rufescentes, e pelo cálice costado.

Ilustrações desta espécie podem ser encontradas em Melo et al. (2009).

3. Euploca procumbens (Mill.) Diane \& Hilger, Bot. Jahrb. Syst. 125: 48. 2003.

= Heliotropium procumbens Mill., Gard. Dict. 8: 10.1768.

Erva ou subarbusto, ca. $20-40 \mathrm{~cm}$ alt., ereto ou prostrado; ramos cinéreos, estrigosos. Folhas alternas; lâmina 1,1-2,8x0,3-1,1 cm, subcarnosa, elíptica a obovada, ápice acuminado, margem levemente revoluta, base atenuada, estrigosa em ambas as faces, venação hifódroma; pecíolo $0,3-1 \mathrm{~cm}$ compr., viloso. Inflorescência 1-4cm compr., escorpióide, axilar e terminal; pedúnculo 0,4-1 cm compr., viloso. Flores ca. $2 \mathrm{~mm}$ compr., subsésseis, ebracteadas; cálice ca. 1,2$1,5 \mathrm{~mm}$ compr., viloso externamente, lacínios ca. $1 \mathrm{~mm}$ compr., estreitamente a largamente elípticos; corola ca. 1,5-1,7mm compr., tubular-hipocrateriforme, alva, serícea externamente, vilosa internamente, lobos ca. 0,5mm compr., ovado-lanceolados; anteras ca. $0,5 \mathrm{~mm}$ compr., ovado-lanceoladas, sésseis; ovário ca. $0,3 \mathrm{~mm}$ compr., globoso, seríceo; estigma ca. 0,3mm compr., cônico, pubescente, subséssil. Esquizocarpo ca. $1 \mathrm{~mm}$ compr., globoso, estrigoso, núculas-4.

Material examinado: BRASIL, Pernambuco: Ibimirim, perímetro irrigado de Moxotó, A.M. Miranda et al. $665,17$. Nov.1992, fl., fr. (PEUFR). Ibidem, Estrada Ibimirim-Petrolândia, M.F. Sales \& C.S. Zickel 599, 03.Jun.1995, fl., fr. (PEUFR).

Euploca procumbens ocorre do sul dos Estados Unidos da América até a Argentina (FROHLICH, 1981) e, no Brasil, em todas as regiões (MELO; SEMIR, 2010) No PNC foi encontrada em caatinga arbustiva e em áreas abertas. Coletada com flores e frutos em junho e novembro.

Esta espécie pode ser seguramente reconhecida pelos ramos cinéreos, corola de lobos ovado-lanceolados e, principalmente, pelo fruto com quatro núculas, estrigoso.

Ilustrações desta espécie podem encontradas em Melo e Semir (2010).

4. Euploca ternata (Vahl) J.I.M. Melo \& Semir, Kew Bull. 64(2): 289. 2009.

= Heliotropium ternatum Vahl, Symb. Bot. 3: 21. 1794. Figura 2: B

Subarbusto, $15-30 \mathrm{~cm}$ alt., ereto ou semiprostrado, geralmente glauco. Folhas alternas, pecioladas ou sésseis; lâmina 0,7-3x0,1-0,5cm, cartácea, estreitamente elíptica, lanceolada a linear, ápice agudo, margem levemente a fortemente revoluta, base aguda, face adaxial esparsa a densamente serícea, face abaxial tomentosa; pecíolo 1-2mm compr., seríceo; venação 
hifódroma. Inflorescência $1,5-18 \mathrm{~cm}$ compr., terminal e axilar; pedúnculo 1,4-2cm compr., viloso; brácteas 2,5-2,7x0,3-0,4mm, lineares a estreitamente elípticas, inconspícuas. Flores 3-4mm compr., subsésseis; cálice profundamente lobado, lacínios com tamanhos levemente diferentes 2-2,5x0,5-0,7mm, ovado-elípticos a lanceolados, seríceos em ambas as faces; corola 3-4mm compr., tubular, alva, fauce amarela, serícea externamente, lacínios 1,3-2mm compr., obovados, estrigosos externamente; estames subsésseis, anteras ca. $1 \mathrm{~mm}$ compr., coerentes entre si, ovadas, base cordada; ovário $0,3-0,4 \mathrm{~mm}$ compr., globoso, glabro; estilete ca. 0,5mm compr.; estigma $0,6-0,8 \mathrm{~mm}$ compr., estreitamente cônico. Esquizocarpo não observado.

Material examinado: BRASIL, Pernambuco: Buíque, Serra de Catimbau, A.M. Miranda et al. 1827, 19.Jun.1994, fl. (PEUFR).

Distribui-se desde o México, Antilhas, Guiana Inglesa, Venezuela e, no Brasil, nas regiões Nordeste (BA, CE, PB, PE, PI, RN, SE), Centro-Oeste (GO) e Sudeste (MG) (MELO; SEMIR, 2010). No PNC foi encontrada com flores em junho.

Caracteriza-se, especialmente, por apresentar brácteas lineares, inconspícuas, cálice profundamente lobado, corola com lacínios obovados e pelo fruto com quatro núculas, densamente hirsuto (MELO; SEMIR, 2010).

Ilustrações desta espécie podem encontradas em Melo e Semir (2010).

5. Heliotropium angiospermum Murray, Prodr. stirp. götting.: 217. 1770.

Erva, ca. 30-50cm alt.; ramos sulcados, escabrosos, hirsutos. Folhas alternas a subopostas; lâmina 2,6-8,6x1$4,5 \mathrm{~cm}$, membranácea, elíptica a largamente elíptica, ápice agudo a acuminado, base oblíqua, pubescente a vilosa em ambas as faces, venação broquidódroma; pecíolo 0,3-1 cm compr., sulcado, viloso. Inflorescência 1,2-22cm compr., escorpióide, terminal e lateral; pedúnculo 0,8-7,5cm compr., viloso. Flores 3,5-4mm compr., sésseis; cálice ca. $3 \mathrm{~mm}$ compr., pubescente externamente, lacínios 2,7-3x0,6-0,8mm, lanceolados; corola 3,5-4mm compr., obcampanulada, alva, vilosa externamente na região do tubo, lobos ca. 1,5mm compr., suborbiculares, acuminados no ápice ou não; estames subsésseis, anteras ca. 1,2mm compr., lanceoladas; ovário ca. $0,5 \mathrm{~mm}$ compr., globoso; estigma ca. $0,6 \mathrm{~mm}$ compr., largamente cônico, séssil. Esquizocarpo ca. $1,8 \mathrm{~mm}$ compr., subgloboso, com apêndices vesiculosos, núculas-2.

Material examinado: BRASIL, Pernambuco: Buíque, Estrada Catimbau-Serra Branca, 08³7'S - 37010'W, M.J.N. Rodal et al. 309, 19.Ago.1994, fl. (PEUFR). Ibidem, Fazenda Pititi, 08³7'30”S 3700'9,15'W, E. Freire et al. 115, 09.Mai.1996, fl., fr. (PEUFR). Ibidem, A. Laurênio et al. 421, 03.Mar.1997, fl., fr. (PEUFR)

Encontrada desde o sul dos Estados Unidos da América até o Brasil, incluindo Antilhas (FROHLICH, 1981). No Brasil, ocorre nas regiões Nordeste e Sudeste (MELO; SEMIR, 2008). No PNC foi encontrada em margem de estrada, vegetação arbustiva densa e herbácea, em altitudes que variaram de 790-799m. Coletada com flores em março, maio e agosto e com frutos em março e maio.

Esta espécie é reconhecida facilmente pelas folhas alternas a subopostas, bem como pelo estigma largamente cônico e frutos portando duas núculas, com apêndices vesiculosos.

Ilustrações para a espécie são encontradas em Melo e Semir (2008).

6. Heliotropium elongatum (Lehm.) I.M. Johnst., Contr. Gray Herb. Harv. Univ. 81: 18. 1928. Figura 2: C

Erva a subarbusto, até $60 \mathrm{~cm}$ alt.; ramos sulcados, vilosos a hirsutos. Folhas alternas; lâmina 2,5-6,4x1,7$3,5 \mathrm{~cm}$, membranácea, bulada, ovada, ápice agudo, base obtusa, margem erosa, face adaxial pubescente a tomentosa, entremeada por longos tricomas aciculares, face abaxial pubescente a vilosa, venação semicraspedódroma; pecíolo 0,6-2,4cm compr., parcialmente alado, viloso. Inflorescência $4,5-11,6 \mathrm{~cm}$ compr., escorpióide, terminal; pedúnculo 1,7-3,6cm compr., pubescente. Flores ca. $6 \mathrm{~mm}$ compr., sésseis; cálice ca. 2,6mm compr., pubescente externamente, lobos ca. $2 \mathrm{~mm}$ compr., estreitamente ovados; corola 5,2-5,7mm compr., tubular-hipocrateriforme, alva, híspida externamente, vilosa internamente, lobos ca. 
$1 \mathrm{~mm}$ compr., orbiculares, patentes; estames sésseis, anteras ca. $1 \mathrm{~mm}$ compr., lanceoladas; ovário ca. $0,5 \mathrm{~mm}$ compr., subgloboso; estilete ca. $0,5 \mathrm{~mm}$ compr.; estigma ca. $0,5 \mathrm{~mm}$ compr., capitado. Esquizocarpo 3,5-4mm compr., mitriforme, núculas-2, justapostas.

Material examinado: BRASIL, Pernambuco: Ibimirim, Estrada Ibimirim-Petrolândia, A. Laurênio \& M. Oliveira 11, 10.Mar.1995, fl., fr. (PEUFR). Ibidem, E. Rodrigues \& F.M.O. Villarouco 13, 10.Mar.1995, fl., fr. (PEUFR).

Ocorre na América do Sul, alcançando à Bolívia, o Paraguai, a Argentina, Uruguai (JOHNSTON, 1928) e, no Brasil, em todas as regiões (MELO; SEMIR, 2008). $\mathrm{Na}$ área de estudo foi registrada em caatinga arbustiva densa sobre latossolo arenoso. Encontrada florida e frutificada em março.

A espécie pode ser reconhecida, principalmente, pelo pecíolo parcialmente alado, associado à corola tubular-hipocrateriforme, com lobos patentes, e pelos frutos mitriformes com duas núculas justapostas.

Ilustrações desta espécie podem encontradas em Melo e Semir (2008).

7. Tournefortia rubicunda Salzm. ex A.DC., Prodr. 9: 526.1845.

Arbusto, ca. $3 \mathrm{~m}$ alt.; ramos decumbentes, glabrescentes, com lenticelas esbranquiçadas. Folhas alternas ou subopostas; lâmina 2,5-8,2x0,7-2,7cm, membranácea, concolor, elíptica a largamente elíptica, ápice agudo, arredondado a emarginado, margem inteira, base oblíqua, estrigosa em ambas as faces, tricomas de base acentuadamente discóide; pecíolo 0,7-1,1 cm compr., sulcado, estrigoso; venação eucamptódroma. Inflorescência $2-4,3 \mathrm{~cm}$ compr., terminal e axilar, laxa; pedúnculo 1,1-1,4cm compr., viloso. Flores 4,8$5,5 \mathrm{~mm}$ compr., sésseis a subsésseis; cálice 1,8-2mm compr., lacínios 1,6-1,9x0,4-0,5mm, lanceolados; corola 4,8-5,2mm compr., tubular-hipocrateriforme, constricta na metade inferior do tubo, alvo-esverdeada, externamente pubescente, internamente glabrescente, lobos 1,2-1,8x0,1-0,2 mm, lineares, involutos; estames inseridos a 2,7-3 $\mathrm{mm}$ da base do tubo, anteras $0,6-1 \mathrm{~mm}$ compr., lanceoladas a ovado-lanceoladas, apiculadas, coerentes; ovário ca. $1 \mathrm{~mm}$ compr., obclavado; estilete 2-2,3mm compr.; estigma ca. $0,5 \mathrm{~mm}$ compr., subpeltado. Drupa $2-3 \mathrm{~mm}$ diâm., discretamente 4-lobada, subglobosa, glabra ou hirsuta apenas na maturidade.

Material examinado: BRASIL, Pernambuco: Buíque, Alcobaça, Faz. Brejo de São José, A. Laurênio \& A.P.S. Gomes 2020, 07.Mai.2003, fr. (PEUFR).

Material adicional examinado: BRASIL, Rio Grande do Norte: Serra Negra do Norte, 21.Abr.2007, J.I.M. Melo et al. 594, fl., fr. (MOSS).

Tournefortia rubicunda ocorre desde o México à América Central, inclusive nas Antilhas, e do norte ao oeste da América do Sul (JOHNSTON, 1930). No Brasil, ocorre desde o Amazonas e Pernambuco até Rio Grande do Sul (JOHNSTON, 1930; CAVALHEIRO et al., 2011). No PNC foi encontrada em vegetação arbustivo-arbórea sobre latossolo arenoso. Coletada com frutos em maio.

Esta espécie pode ser seguramente reconhecida com base, principalmente, na lâmina foliar concolor com tricomas rubicundos e, também, pelo ovário obclavado e estigma subpeltado.

Ilustrações desta espécie podem ser encontradas em Melo e Andrade (2007) e Cavalheiro et al. (2011).

8. Tournefortia salzmannii DC., Prodr. 9: 524. 1845. Figura 2: D

Arbusto, ca. $2 \mathrm{~m}$ alt.; ramos vilosos quando jovens, castanhos, com lenticelas. Folhas alternas; lâmina 2-11x1-6,5cm, membranácea, estreitamente a largamente ovada, ápice acuminado, margem inteira, base cuneada, estrigosa em ambas as faces, rufescente em ambas as faces ou apenas abaxialmente; pecíolo 0,3-1 cm compr., subcilíndrico, viloso; venação broquidódroma. Inflorescência 1,8-11,2cm compr., escorpióide com ramos secundifloros, terminal e lateral; pedúnculo 0,7 1,7cm compr., viloso. Flores 3-5mm compr., subsésseis; cálice ca. $3 \mathrm{~mm}$ compr., viloso, lacínios 1-2mm compr., estreitamente elípticos, ápices cirrosos ou não; corola ca. $5 \mathrm{~mm}$ compr., tubular, alvo-esverdeada, vilosa, lobos ca. $2 \mathrm{~mm}$ compr., lineares, involutos; estames subsésseis, anteras ca. $0,5 \mathrm{~mm}$ compr., coerentes, ovadas, tricomas no ápice, este apiculado; ovário ca. $1 \mathrm{~mm}$ compr., cônicopiramidal; estilete ca. 1,6mm compr.; estigma ca. $0,4 \mathrm{~mm}$ compr., estreitamente cônico, levemente bífido no ápice, pubescente. Drupa não observada. 
Material examinado: BRASIL, Pernambuco: Buíque, Sítio Pititi, Serra Branca, A.P.S. Gomes \& M.J.N. Rodal 332, 12.Abr.1996, bot. fl. (PEUFR).

Material adicional examinado: BRASIL, Rio Grande do Norte: Patu, Serra do Lima, 30.Abr.2008, J.I.M. Melo et al. 661, fl., fr. (MOSS).

Encontrada na Argentina, Paraguai, Bolívia (JOHNSTON, 1930) e, no Brasil, nas regiões Nordeste, Sudeste e Sul (CAVALHEIRO et al., 2011). Na área de estudo foi encontrada em vegetação arbustivo-arbórea sobre solo arenoso, esbranquiçado. Coletada com botões florais em abril.

Tournefortia salzmannii pode ser reconhecida principalmente por apresentar lâmina foliar rufescente em ambas às faces ou apenas abaxialmente, ovário cônico-piramidal e estigma estreitamente cônico levemente bífido no ápice.

Ilustrações desta espécie podem ser encontradas em Melo e Andrade (2007) e Cavalheiro et al. (2011).

9. Varronia curassavica Jacq., Enum. Syst. P1.: 14. 1760 .

= Cordia curassavica (Jacq.) Roem. \& Schult., Syst. Veg. 4: 460. 1819.

Arbusto, ca. 1,5m alt.; ramos vilosos, sulcados. Folhas alternas; lâmina 5,5-10,6×2-3,7cm, membranácea, lanceolada, ápice agudo, margem serreada, base atenuada, face adaxial glabrescente, face abaxial vilosa, venação semicraspedódroma; pecíolo ca. 1,2cm compr., sulcado, viloso, decurrente. Inflorescência 3,3-6cm compr., espiciforme, congesta, terminal e axilar; pedúnculo 3,5-4,7 cm compr., viloso. Flores ca. $4 \mathrm{~mm}$ compr., sésseis; cálice ca. $3,7 \mathrm{~mm}$ compr., obcampanulado, pubescente, lacínios ca. $1,2 \mathrm{~mm}$ compr., trulados; corola ca. $3 \mathrm{~mm}$ compr., tubular-salverforme, alva a creme, vilosa internamente, lobos ca. $1 \mathrm{~mm}$ compr., oval-lanceolados; estames subsésseis, anteras ca. $0,5 \mathrm{~mm}$ compr., oblongas, divaricatas, filetes ca. $0,5 \mathrm{~mm}$ compr.; ovário ca. 0,5mm compr., ovóide; estilete ca. $1,5 \mathrm{~mm}$ compr.; ramos estigmáticos ca. $0,5 \mathrm{~mm}$ compr., estigmas- 4 , ca. $0,3 \mathrm{~mm}$ compr., clavados, vilosos, tricomas castanhos e ferrugíneos. Drupa ca. 4mm compr., ovóide.
Material examinado: BRASIL, Pernambuco: Buíque, Estrada Buíque-Catimbau, 08³7’30"S 3700'9,15"W, A. Laurênio 43, 18.Mar.1995, fl., fr. (PEUFR). Ibimirim, BR-316, D. Belo s.n., 09.Jan.1990, fl. (PEUFR 09716).

Ocorre do norte do México ao nordeste da América do Sul, incluindo as Antilhas (MILLER, 1988). No Brasil, pode ser encontrada em todas as regiões; em ambientes de cerrado, restinga e floresta (TARODA, 1984). No PNC foi encontrada em vegetação arbustiva densa sobre solo alaranjado, a 799m de altitude. Coletada com flores em janeiro e março e frutos em março.

Assemelha-se morfologicamente à Varronia dardani, com a qual compartilha, principalmente, as inflorescências espiciformes. No entanto, pode ser diferenciada desta pela lâmina foliar lanceolada, concolor, de base atenuada, bem como pelo cálice pubescente e frutos ovóides.

Ilustrações desta espécie podem ser encontradas em Melo e Sales (2005).

10. Varronia dardani (Taroda) J.S. Mill., Novon 17(3): 373. 2007.

= Cordia dardani Taroda, Notes Roy. Bot. Gard. Edinburgh 44(1): 111. 1986.

Arbusto, ca. $1 \mathrm{~m}$ alt.; ramos subcilíndricos. Folhas alternas; lâmina 2,5-4,6x1,1-1,9cm, discolor, subcartácea, ovada a ovado-elíptica, ápice obtuso, margem crenulada, base levemente cordada, face adaxial puberulenta, bulada, face abaxial vilosa, rufescente, venação semicraspedódroma; pecíolo ca. $0,6 \mathrm{~mm}$ compr., sulcado, viloso. Inflorescência 1,5-3,4cm compr., espiciforme, congesta, terminal e axilar; pedúnculo 1,3-2cm compr., densamente viloso, rufescente. Flores ca. $5 \mathrm{~mm}$ compr., sésseis; cálice ca. 2,7mm compr., obcônico, tomentoso, lacínios diminutos, ovados; corola ca. 4,3mm compr., tubularsalverforme, alva a creme, pubescente externamente, internamente vilosa na região do tubo, lobos diminutos, truncados; estames subsésseis, anteras ca. $0,8 \mathrm{~mm}$ compr., oblongas, divaricatas; ovário ca. $1 \mathrm{~mm}$ compr., piriforme; estilete ca. $2,7 \mathrm{~mm}$ compr.; ramos estigmáticos ca. $0,2 \mathrm{~mm}$ compr., estigmas- 4 , ca. $0,3 \mathrm{~mm}$ compr., foliáceos, vilosos. Drupa não observada. 
Material examinado: BRASIL, Pernambuco: Buíque, brejo de altitude, G.P. Machado s.n., 16.Fev.2004, fl. (PEUFR 46283).

Ocorre apenas no nordeste do Brasil, em vegetação de caatinga. Encontrada, até o momento, nos estados de Pernambuco, Sergipe, Alagoas e Paraíba (MELO et al., 2012). No PNC foi coletada com flores em fevereiro, sendo localmente conhecida como moleque duro.

Esta espécie é reconhecível, principalmente, pelas inflorescências espiciformes associadas à lâmina foliar ovada, discolor, de base levemente cordada ou, ainda, pelo cálice rufescente e fruto piriforme quase inteiramente recoberto pelo cálice (MELO; ANDRADE, 2007).

Ilustrações desta espécie podem ser encontradas em Melo e Sales (2005) sob o gênero Cordia (C. dardani Taroda).

11. Varronia globosa Jacq., Enum. Syst. Pl.: 14. 1760.

$=$ Cordia globosa (Jacq.) Kunth in Humb., Bonpl. \& Kunth, Nov. Gen. et Sp. 3: 76. 1819. Figura 2: $\mathrm{E}$

Arbusto, ca. 1-2m alt.; ramos com lenticelas, vilosos. Folhas alternas; lâmina 5,3-6,7x1,8-2,6mm, discolor, membranácea, elíptica a lanceolada, ápice agudo, margem serreado-denteada, base oblíqua, face adaxial vilosa, face abaxial tomentosa, venação craspedódroma; pecíolo 0,5-0,6mm compr., viloso. Inflorescência glomérulo-globosa, congesta, axilar e supra-axilar; pedúnculo $1,8-4 \mathrm{~cm}$ compr. Flores ca. 4,5mm compr., sésseis; cálice ca. $3 \mathrm{~mm}$ compr., campanulado, lacínios 1-1,2mm compr., ovados, de ápice cirroso, com curtos tricomas ferrugíneos nas margens; corola ca. 4,5mm compr., infundibuliforme, alva a amarelada, vilosa internamente e externamente, lobos ca. $1 \mathrm{~mm}$ compr., orbiculares; estames subsésseis, anteras ca. $0,7 \mathrm{~mm}$ compr., oblongas, divaricatas, dorsifixas; ovário 1-1,2mm compr., cônico; estilete ca. $3 \mathrm{~mm}$ compr., viloso na porção superior; ramos estigmáticos ca. $0,5 \mathrm{~mm}$ compr., estigmas- 4 , ca. $0,7 \mathrm{~mm}$ compr., foliáceos, pubescentes. Drupa não observada.

Material examinado: BRASIL, Pernambuco: Buíque, Sítio Pititi, Serra Branca, A. Laurênio et al.
448, 11.Abr.1997, fl. (PEUFR). Ibimirim, Fazenda Mandacaru, M.C. Tschá et al. 565, 16.Fev.1996, fl. (PEUFR).

Distribui-se do sudeste da Flórida ao nordeste da América do Sul, incluindo Antilhas (MILLER, 1988). Segundo Melo et al. (2010), no Brasil ocorre apenas na região Nordeste (CE, RN, PB, PE, AL, BA) restringindose à Caatinga. No $\mathrm{PNC}$ foi encontrada no sopé de serra e em vegetação arbustivo-arbórea sobre solo arenoargiloso. Coletada com flores em fevereiro e abril.

Varronia globosa pode ser reconhecida facilmente pela lâmina foliar discolor, inflorescências gloméruloglobosas com flores ca. $4 \mathrm{~mm}$ compr. e pelo fruto elipsóide quase inteiramente recoberto pelo cálice (MELO; ANDRADE, 2007).

Ilustrações para a espécie são encontradas em Melo e Sales (2005) e Melo e Andrade (2007) sob o gênero Cordia (C. globosa (Jacq.) Kunth).

12. Varronia leucocephala (Moric.) J.S. Mill., Novon 17 (3): 374. 2007.

= Cordia leucocephala Moric., P1. Nouv. d'Americ. 148: 88. 1846. Figura 2: F

Arbusto, ca. 0,4-2m alt.; ramos vilosos entremeados por tricomas diminutos. Folhas alternas; lâmina 2,9-8,5x1,1-4,3cm, discolor, membranácea, estreitamente a largamente ovada, ápice acuminado ou retuso, margem serreada, base cuneada, face adaxial estrigosa a vilosa, face abaxial pubescente a tomentosa, venação craspedódroma; pecíolo $0,3-0,9 \mathrm{~cm}$ compr., viloso, tricomas ferrugíneos. Inflorescência gloméruloglobosa, terminal; pedúnculo 1,4-4,5cm compr., viloso. Flores 2,5-3,5cm compr., sésseis; cálice ca. $5 \mathrm{~mm}$ compr., pubescente, lacínios 1,5-2mm compr., ovados, de ápice agudo; corola 2,3-3 cm compr., infundibuliforme, alva, lobos 2-3x6,5-8mm, largamente ovados, emarginados; estames com filetes 1,5-2mm compr., anteras ca. 1,7mm compr., oblongas, divaricatas, dorsifixas; ovário ca. $1,5 \mathrm{~mm}$ compr., estreitamente ovado; estilete ca. 2,5mm compr.; ramos estigmáticos ca. $0,2 \mathrm{~mm}$ compr., estigmas-4, ca. $1 \mathrm{~mm}$ compr., foliáceos. Drupa não observada.

Material examinado: BRASIL, Pernambuco: Buíque, Estrada Buíque-Catimbau, $08^{\circ} 37^{\prime} \mathrm{S}-37^{\circ} 10^{\prime} \mathrm{W}$, 
L. Figueiredo \& K. Andrade 78, 16.Jun.1995, fl. (PEUFR). Ibidem, Faz. Laranjeiras, A. Laurênio \& A.P.S. Gomes 414, 07.Dez.1996, fl. (PEUFR). Ibimirim, M. Sales et al. 38, 22.Nov.1986, fl. (PEUFR). Ibidem, Faz. Mandacaru-Casa Nova, $08^{\circ} 29,4^{\prime}$ S $-35^{\circ} 41^{\prime} \mathrm{W}, A$. Laurênio et al. 314, 16.Fev.1996, fl. (PEUFR). Ibidem, Faz. Laranjeiras, A. Laurênio \& A.P.S. Gomes 414, 07.Dez.1996, fl. (PEUFR).

Ocorre apenas na região nordeste do Brasil, associada à vegetação de caatinga (TARODA, 1984; MELO; SALES, 2005) e no litoral, em ambientes de restingas (MELO; SALES, 2005). No PNC foi encontrada em margem de estrada e em vegetação arbustiva e arbustivo-arbórea densa sobre latossolos areno-argilosos estes por vezes com afloramentos rochosos. Coletada com flores em fevereiro, junho e dezembro.

Pode ser reconhecida, principalmente, pelas inflorescências glomérulo-globosas portando flores com cálice de ápice agudo e corola com 2,3-3cm compr., infundibuliforme, alva.

Ilustrações desta espécie podem ser encontradas em Melo e Sales (2005) e Melo e Andrade (2007) sob o gênero Cordia (C. leucocephala Moric.).

\section{Referências}

ALBACH, D. C.; SOLTIS, P. S.; SOLTIS, D. E.; OLMSTEAD, R. G. Phylogenetic analysis of asterids based on sequences of four genes. Annals of the Missouri Botanical Garden, Saint Louis, v. 88 , p. 163-212, 2001

ANDRADE, G. O. A Serra Negra - Uma relíquia geomorfológica e higrófita nos tabuleiros pernambucanos. Recife: Imprensa Oficial, 1954. $75 \mathrm{p}$.

ANGIOSPERM PHYLOGENY GROUP I. An ordinal classification for the families of flowering plants. Annals of the Missouri Botanical Garden, Saint Louis, v. 85, p. 531-553, 1998.

ANGIOSPERM PHYLOGENY GROUP II. An update of the Angiosperm Phylogeny Group classification for the orders and families of flowering plants: APG II. Botanical Journal of the Linnean Society, London, v. 141, p. 399-436, 2003.

ANGIOSPERM PHYLOGENY GROUP III. An update of the Angiosperm Phylogeny Group classification for the orders and families of flowering plants. Botanical Journal of the Linnean Society, London, v. 161, p. 105-121, 2009.

BÖHLE, U. R.; HILGER, H. H. Chloroplast DNA systematics of "Boraginaceae" and related families: a goodbye to the old familiar concept of 5 subfamilies. Scripta Botanica Belgica, Bruxelles, v. 15 , p. 30,1997
BREMER, B.; BREMER, K.; HEIDARI, N.; ERIXON, P.; OLMSTEAD, R. G.; ANDERBERG, A. A.; KÄLlERSJÖ, M.; BARKHORDARIAN, E. Phylogenetics of asterids based on 3 coding and 3 non-coding chloroplast DNA markers and the utility of non-coding DNA at higher taxonomic levels. Molecular Phylogenetics and Evolution, Oxford, v. 24, p. 274-301, 2002.

CAVAlHEIRO, L.; RANGA, N. T.; FURLAN, A. Tournefortia L. (Boraginaceae): espécies do Brasil extra-amazônico. Hoehnea, São Paulo, v. 38, n. 2, p. 221-242, 2011.

CRONQUIST, A. An integrated system of classification on flowering plants. New York: Columbia University Press, 1981. 1262 p.

FROHLICH, M. W. Heliotropium. In: NASH, D. L.; MORENO, N. P. (Ed.). Flora de Veracruz: Boraginaceae. v. 18. Xalapa: Instituto Nacional de Investigaciones sobre Recursos Bióticos, 1981. p. 70104.

GOTTSCHLING, M.; HILGER, H. H.; WOLF, M.; DIANE, N. Secondary structure of the ITS1 transcription and its application in a reconstruction of the phylogeny of Boraginales. Plant Biology, Dundee, v. 3, p. 629-636, 2001.

HARRIS, J. G.; HARRIS, M. W. Plant identification terminology: an illustrated glossary. Utah: Spring Lake Publishing, 1997. 188 p.

HEWSON, H. J. Plant Indumentum - a handbook of terminology. Canberra: Bureau of Flora and Fauna (Australian Flora and Fauna Series, 9), 1988. p. 1-27.

HICKEY, L. J. Classification of the architecture of dicotyledonous leaves. American Journal of Botany, Columbus, v. 60, p. 17-33, 1973.

JACOMINE, P. K. T.; CAVALCANTI, A. C.; BURGOS, N.; SILVEIRA, C. O. 1973. Levantamento exploratório Reconhecimento de solos do estado de Pernambuco. Recife: SUDENE, 1973. p. 1-175. (Boletim Técnico, n. 26).

JOHNSTON, I. M. Studies in Boraginaceae VII: The South American species of Heliotropium. Contributions from the Gray Herbarium of Harvard University, Cambridge, v. 81, p. 3-73, 1928.

JOHNSTON, I. M. Studies in Boraginaceae VIII: Observations on the species of Cordia and Tournefortia known from Brazil, Paraguay, Uruguay and Argentina. Contributions from the Gray Herbarium of Harvard University, Cambridge, v. 92, p. 3-89, 1930.

JUDD, W. S.; CAMPBELL, C. S.; KELLOGG, E. A.; STEVENS, P. F.; DONOGHUE, S. J. Sistemática vegetal: um enfoque filogenético. 3. ed. Porto Alegre: Artmed, 2009. 632 p.

MELO, J. I. M.; ANDRADE, W. M. Boraginaceae s.l. A. Juss. em uma área de Caatinga da ESEC Raso da Catarina, Bahia - Brasil. Acta Botanica Brasilica, São Paulo, v. 21, n. 2, p. 369-378, 2007.

MELO, J. I. M.; LOPES, C. G. R.; FERRAZ, E. M. N. Boraginaceae A. Juss. senso lato em uma floresta estacional de terras baixas em Pernambuco - Brasil. Revista Caatinga, Mossoró, v. 22, n. 3, p. 179-186, 2009.

MELO, J. I. M.; SALES, M. F. Boraginaceae A. Juss. na região de Xingó: Alagoas e Sergipe. Hoehnea, São Paulo, v. 32, n. 3, p. 369-380, 2005

MELO, J. I. M.; SEMIR, J. Taxonomia do gênero Heliotropium L. (Heliotropiaceae) no Brasil. Acta Botanica Brasilica, Feira de Santana, v. 22, n. 3, 754-770, 2008. 
MELO, J. I. M.; SEMIR, J. Taxonomia do gênero Euploca Nutt. (Heliotropiaceae) no Brasil. Acta Botanica Brasilica, Feira de Santana, v. 24, n. 111-132, 2010.

MELO, J. I. M.; SILVA, L. C.; STAPF, M. N. S.; RANGA, N. T. Boraginaceae. In: FORZZA, R. C. et al. (Ed.). Catálogo de plantas e fungos do Brasil. Rio de Janeiro: Jardim Botânico do Rio de Janeiro, 2010. p. 773-777.

MELO, J. I. M.; SILVA, L. C.; STAPF, M. N. S.; RANGA, N. T. Boraginaceae. In: FORZZA, R. C. et al. (Org.). Lista de espécies da flora do Brasil. Rio de Janeiro: Jardim Botânico do Rio de Janeiro. 2012. Disponível em: <http: //floradobrasil.jbrj.gov. br/2010/FB016555>. Acesso em: 27 mar. 2012.

MILLER, J. S. A revised treatment of Boraginaceae for Panama. Annals of the Missouri Botanical Garden, Saint Louis, v. 75, n. 2, 456-521, 1988.

MOREIRA, A. A. N. Relevo. In: IBGE (Ed.). Geografia do Brasil - Região Nordeste. Rio de Janeiro: Instituto Brasileiro de Geografia e Estatística, 1977. p. 1-45.

PAYNE, W. W. A glossary of plant hair terminology. Brittonia, New York, v. 30, p. 239-255, 1978.
RADFORD, A. E.; DICKISON, W. C, MASSEY, J. R., BELL, C. R. Vascular plant systematics. New York: Harper \& Row Publish., 1974. $891 \mathrm{p}$

RANGA, N. T.; MELO, J. I. M.; SILVA, L. C. Boraginaceae. In: CAVAlCANTI, T. B.; SILVA, A. P. (Org.). Flora do Distrito Federal, Brasil. Vol. 9. Brasília: EMBRAPA/CENARGEN, 2011. p. 47-67.

SOLTIS, P. S.; SOLTIS, D. E.; SAVOLAINEN, V.; CRANE, P. R.; BARRACLOUGH, T. G. Rate heterogeneity among lineages of tracheophytes: integration of molecular and fossil data and evidence for molecular living fossils. Proceedings of the National Academy Sciences of the United States of America, Philadelphia, V. 99, p. 4430-4435, 2002.

STRASBURGER, E. A.; NOLL, F.; RUDOLF, J. Tratado de Botánica. Barcelona: Editorial Marin, 1974. 798 p.

TARODA, N. Taxonomic studies on Brazilian species of Cordia (Boraginaceae). PhD Thesis - University of Saint Andrews, Saint Andrews, 1984. $231 \mathrm{p}$.

WEBERLING, F. Morphology of flowers and inflorescences. Cambridge: University Press, 1995. 405 p. 